\title{
Implementation and Reinforcement of Student Character Education in Palembang City
}

\author{
Mardiah Astuti ${ }^{1}$, Fajri Ismail ${ }^{2}$, Padjrin 3 \\ DOI: 10.35445/alishlah.v13i2.638
}

\section{Article Info}

Keywords:

Reinforcement;

Character building;

Student character

Kata kunci:

Penguataan;

Pendidikan Karakter;

Karakter siswa

\begin{abstract}
The study aimed to analyze the inculcation of student character values in schools in Palembang City. The study used a quantitative descriptive method. The data collection used observation, questionnaires, and documentation. The sample of the research was 66 samples with quota sampling technique. The study found that the lack of exemplary reinforcement and habituation decreased the understanding and reflection of students' behavioral character values. Furthermore, learning about character values was integrated through the subjects of Civics and Islamic Religious Education. While the school gave the exemplary family and community reinforcement in the form of regulations, policies, and cooperation between schools, families, and communities regularly, as well as habituation of living with character in daily life was still not optimal. It needed to be optimized again so that the character values in students were closely and maximally attached to students both from speech and action.
\end{abstract}

\begin{abstract}
Abstrak
Penelitian ini bertujuan untuk menganalisis penanaman nilai karakter siswa di sekolah di Kota Palembang. Penelitian ini menggunakan metode deskriptif kuantitatif. Pengumpulan data menggunakan observasi, angket dan dokumentasi. Sampel penelitian ini sebanyak 66 sampel dengan teknik quota sampling. Penelitian ini menemukan bahwa kurangnya keteladanan, penguatan dan pembiasaan merupakan faktor menurunnya pemahaman dan pencerminan nilai-nilai karakter perilaku siswa. Selanjutnya pembelajaran tentang nilai-nilai karakter diintegrasikan melalui mata pelajaran Pendidikan Kewarganegaraan (PKn) dan Pendidikan Agama Islam. Sedangkan keteladanan yang diberikan pihak sekolah, keluarga dan masyarakat, penguatan dalam bentuk peraturan, kebijakan, dan kerjasama antara sekolah, keluarga dan masyarakat secara berkala, serta pembiasaan hidup berkarakter dalam kehidupan sehari-hari masih belum optimal. Dan perlu dioptimalkan lagi agar nilai-nilai karakter pada siswa melekat erat dan maksimal pada diri siswa baik dari ucapan maupun tindakan.
\end{abstract}

${ }^{1}$ UIN Raden Fatah Palembang, Indonesia Email: mardiahastuti_uin@radenfatah.ac.id 2 UIN Raden Fatah Palembang, Indonesia Email: fajriismail_uin@radenfatah.ac.id 3 SMP Negeri o3 Palembang, Indonesia

Email: dhapadjrin@gmail.com 


\section{INTRODUCTION}

Moral decadence had been rampant in the world of education so that it had become a blurry portrait in the world of education. It can be seen from the rise of negative behavior by students such as fights, cheating, drugs, and others. Character degradation was a matter of concern. The problem of decreasing student character occurred in various regions in Indonesia and even the world. In a study conducted on students in Pekalongan, the deviant behavior encountered in student violence, fights, beatings, and courtship exceeded the limit or showed characterless behavior (Yuniati A, 2017).

The research conducted by the International Center for Research on Women (ICRW) in five Asian countries, namely Vietnam, Cambodia, Nepal, Pakistan, and Indonesia, showed that 84\% of acts of violence against students occurred in schools in 2015 (ICRW, 2015). In 2016, in Indonesia alone, violence occurred; the perpetrators were 135 students (Gunawan \& Hafiz, 2020). The nature of aggression, physical fights, threatening, and hurting other students showed the lack of character in students. In a study, this attitude was caused by naughty peer affiliation, weak parental monitoring, poor school performance affecting character (Li \& Cheng, 2017).

The character can be formed through education (Asa, 2019). A good education guided one's life (Sudrajat, 2011) and was useful in developing one's potential for the good things needed by him, society, and the state. So that students did have high knowledge and had high character (Rachmadyanti, 2017). Individuals with the character had a sense of love, responsibility, honesty, courtesy, caring, compassion, humility, tolerance, peace-loving, and all other good behavior. Religious values were things that can be applied in character education (Anwar, 2016). The children would become good people if they grew up in exemplary and good habits (Suyanto, 2012). Being identified by the National Research Council, the character was a prerequisite for a person's development in life and work (Lavy, 2020).

The human character was a good behavior as a gift from Allah SWT to humans and was formed and developed from opinions, thoughts, attitudes, and actions (Achmad, 2020; Hasan, 2011; Padjrin, 2016). In general, the human character had good (taqwa) and evil (fujur) traits. Actualization of character development was done by maximizing good (taqwa) and minimizing evil characters (Achmad, 2020). Good character was related to good behavior, such as loving-kindness and behaving well, so that it emerges from within him a good character, having high self-confidence, being honest, respectful, caring, responsible, disciplined, brave, honest, diligent, and with integrity (Anwar, 2016; Sudrajat, 2011; Zuhdi, 2011). This behavior can be formed through the educational process. In Indonesia, it was called character education. Character education was contained in the seven philosophies and messages of K.H. Ahmad Dahlan, which included visionary or thinking ahead (Sutarna et al., 2021).

Research conducted by Tang (2019) found that the character of curiosity and self-control had a significant effect on academic achievement. In comparison, the character of caring, curiosity, and self-control had a significant effect on student welfare. Character can be formed in four ways, namely: the first was learning. All components of education must instill character values in the family, school, and community environment. It was in line with what was shown in a study that stated that character values must be instilled, practiced by all components of education, and integrated into every subject (Rosad, 2019; Sudrajat, 2011). The character can be developed through problem-solving program-based learning that positively affects character (S. Kim et al., 2019) or educational media. Educational media had a positive impact on children's knowledge (Borzekowski, 2018). Character learning can be through character education. It included character knowing or awareness of character, knowledge of character values, ability to take lessons, ability to take an attitude when facing problems and know yourself. Character feeling (feelings about the character) consisted of conscience, which was knowledge of the truth, and having a sense of obligation to do what was right, self-esteem which was treating and respecting others positively as we want to be treated or appreciated, humility, empathy, self-control, and loving the good. Moreover, character 
action resulted from character knowledge and character feelings, namely listening, expressing, and formulating (Rosad, 2019).

The second was exemplary. Character values must be exemplified continuously by all school components. Exemplary through cognitive, affective, and psychomotor aspects was the most effective and essential method of character education if it was carried out thoroughly by teachers in the educational environment (Munawwaroh, 2019; Rosad, 2019; Sudrajat, 2011). The third was reinforcement. School life with the commendable character was realized if it was supported by environmental arrangements and support activities such as smile banners, greetings, and greetings in the school environment, regular involvement of family collaboration for students who skipped school, liked to be angry, and so on (Rosad, 2019; Sudrajat, 2011). Furthermore, the fourth was habituation. Habituation in discipline was a strategic step in shaping the character that leaders can implement, educators, students, and education staff in the educational environment (Rosad, 2019; Sudrajat, 2011). Social ethics, dress etiquette, punctuality, and students' character towards education staff, educators, and leaders were character habits implemented in schools. Character habituation can also be lived through learning, extracurricular and intra-curricular activities (Rosad, 2019).

In the research, Saptatiningsih (2021) explained that character education materials indoctrinated with the indoctrination method informal institutions would not build the nation's character because the implementation of character can only be built based on habits, spiritual and affective values. Unlike previous research, this study analyzes the inculcation of student character values in schools in Palembang City. This study will see how exemplary, strengthening, and habituation in character education is carried out.

\section{METODE}

The study used a quantitative descriptive method. The study population was teachers and students at the elementary, junior high, and high school levels in Palembang City for the 2020/2021 academic year. The study populations were 340 elementary, junior high, and high school students. With quota sampling technique, the samples were 66 people, consisting of 20 elementary school students, 20 junior high school students, 20 high school students, 2 elementary school teachers, 2 junior high school teachers, and 2 high school teachers. Data were collected through observation, questionnaires, and documentation for three months, from February to April 2021. Then the data were analyzed using quantitative descriptive.

\section{FINDINGS AND DISCUSSION}

\section{Learning}

Learning about character values was obtained by students from the school environment, family, and community. This learning can be seen from the results of the questionnaire in Figure 1:

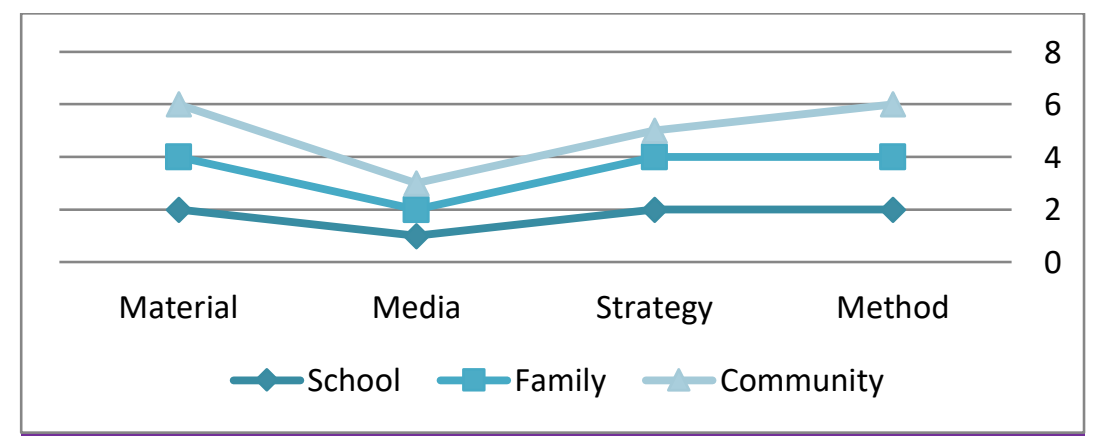

Figure 1. Implementation of Character Education in the Learning Process

Learning about character values was obtained from the school, family, and community environment. Learning character values in schools were reflected in religious subjects, citizenship, and all subjects integrated into character values. In the family environment, character values were 
given in the form of advice, while in the community environment, the learning of character values was reflected in local, regional policies. More details are in Figure 2:

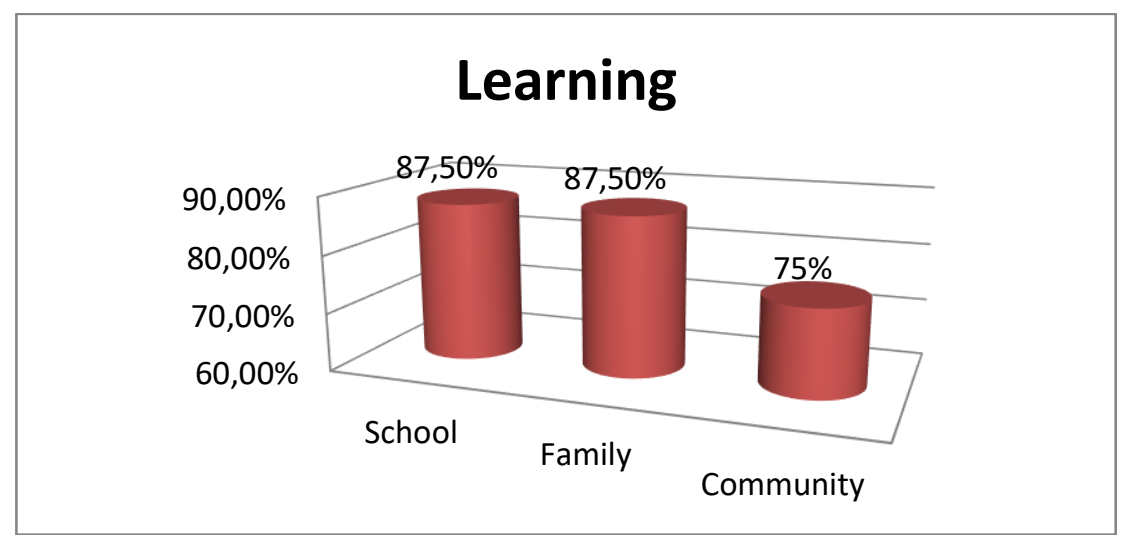

Figure 2. The percentage of learning about character values in the school, family, and community environment

\section{Exemplary}

In general, students got exemplary from teachers in the school environment, parents in the family environment, and neighbors in the community. More details are in Figure 3:

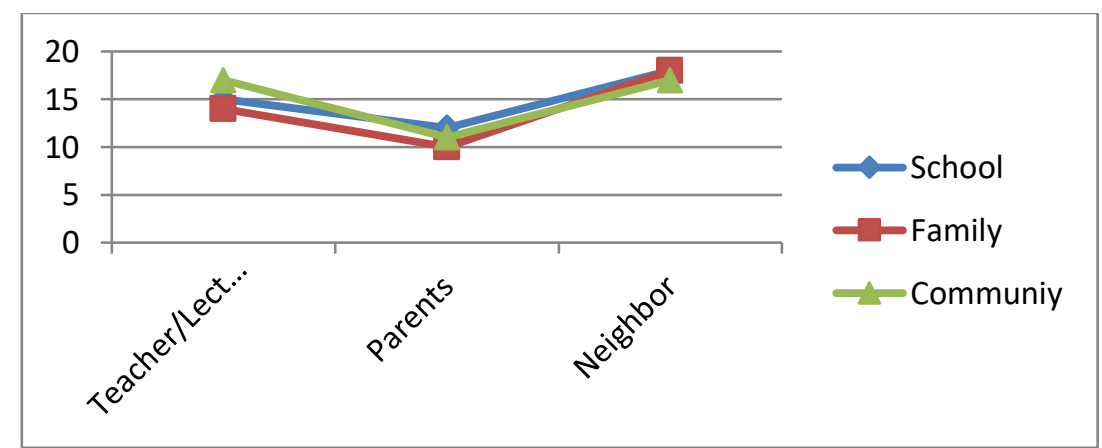

Figure 3. Exemplary of students in school, family, and community

Exemplary as above, was mostly done at the school and the family. More details can be seen in Figure 4:

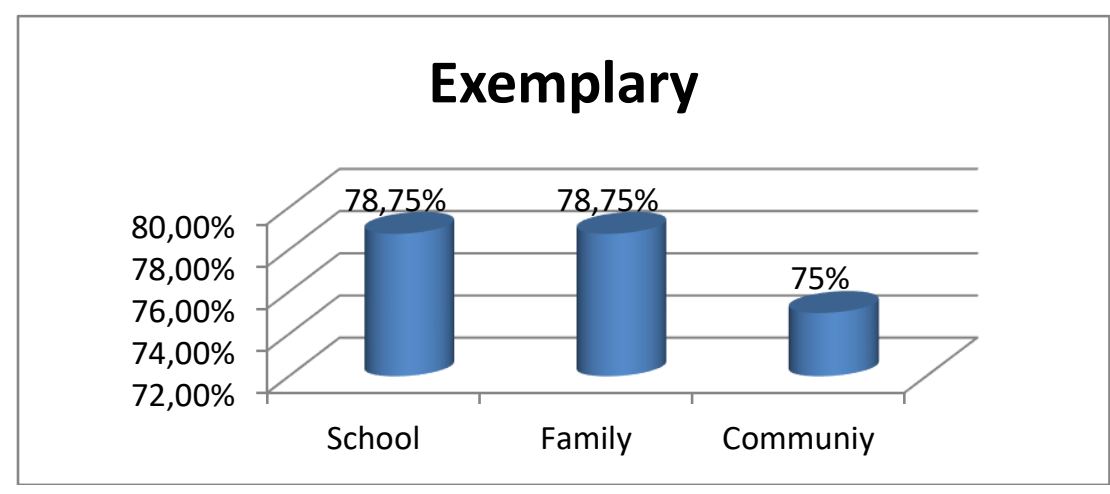

Figure 4. Percentage of exemplary aspects of character education in school, family, and community

\section{Reinforcement}

In general, reinforcement of character values in school, family, and community provides motivation, discipline, regulations, policies, supervision, and regular communication. In a study, character values were given to students every Monday in a flag ceremony through the speech of the ceremony supervisor (Virgustina, 2019). 
The results of the questionnaire showed that the reinforcement of character values given to elementary, junior, and senior high school students in Palembang city was shown in Figure 5:

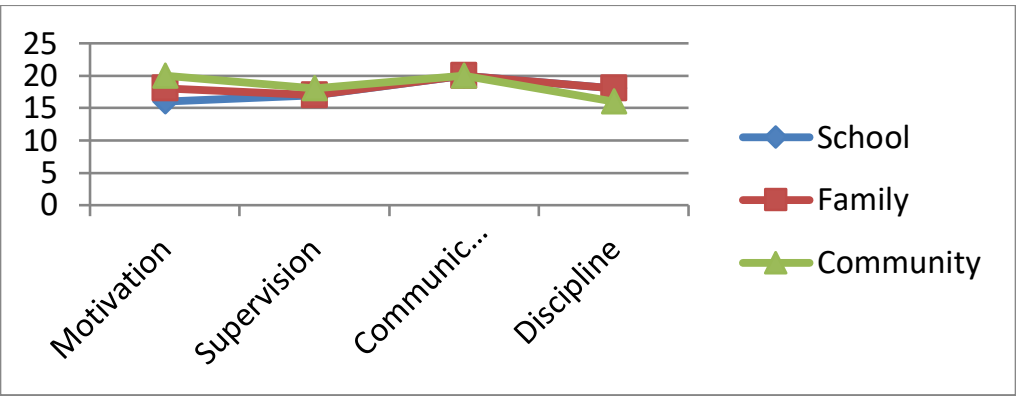

Figure 5. Reinforcement of character values in students in the school, family, and community

The school environment dominated the reinforcement given. Reinforcement was given in the form of motivation, supervision, intense communication, and discipline. The percentage of reinforcement of character education for students in Palembang City was as shown in Picture 6:

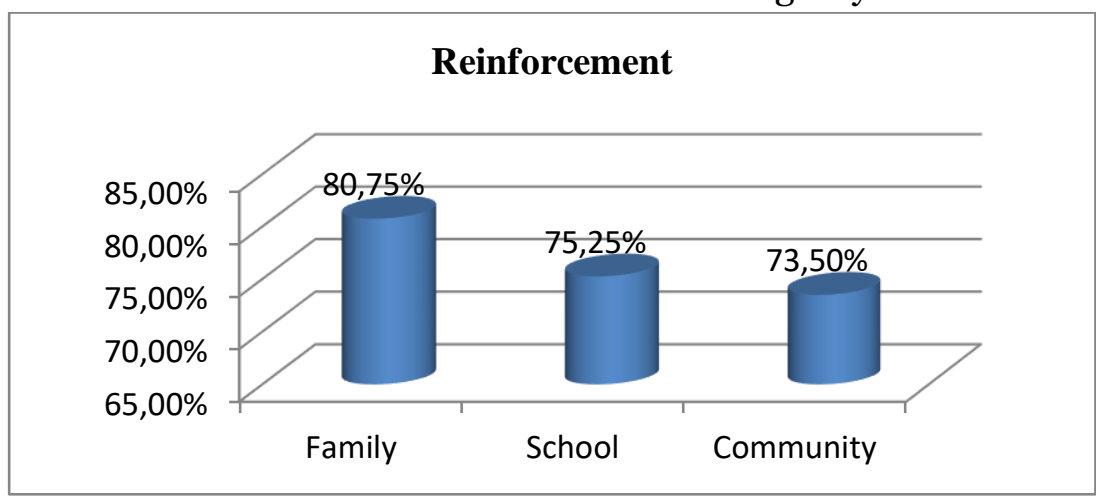

Figure 6. Percentage of reinforcement aspects of character education in school, Habituation family, and community

Habituation in cultivating character values was generally carried out through school, family, and community regulations. The family had a role for their children, namely: teaching The loss of role models from parents and a less conducive environment were problems in character education for students (Julaeha, 2019). The lack of support from parents of students was one of the factors causing the cultivation of character values that has not been running optimally (Marzuki, 2018). As in Figures 7 and 8:

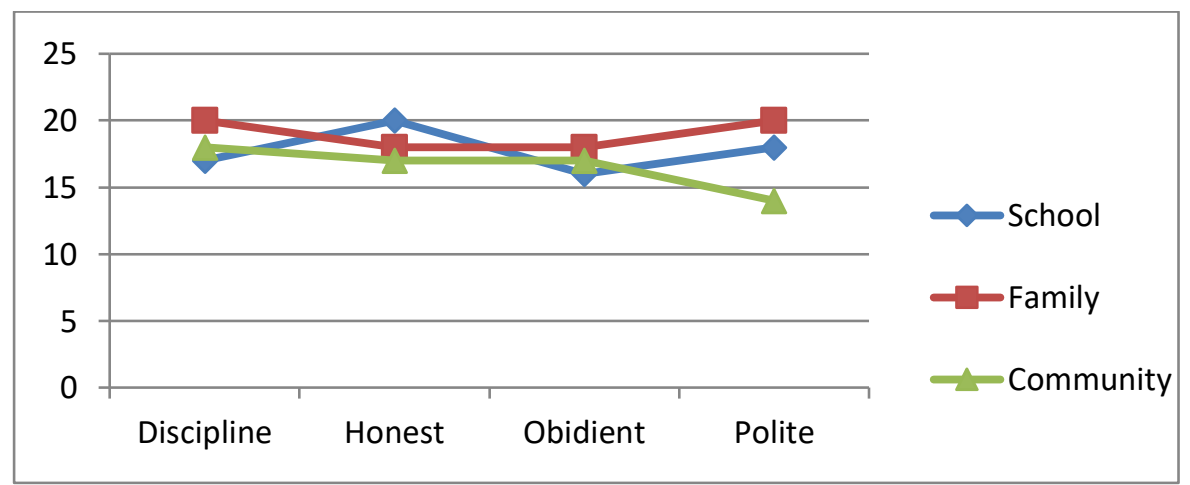

Figure 7. Habituation of character values in students at school, family, and community 


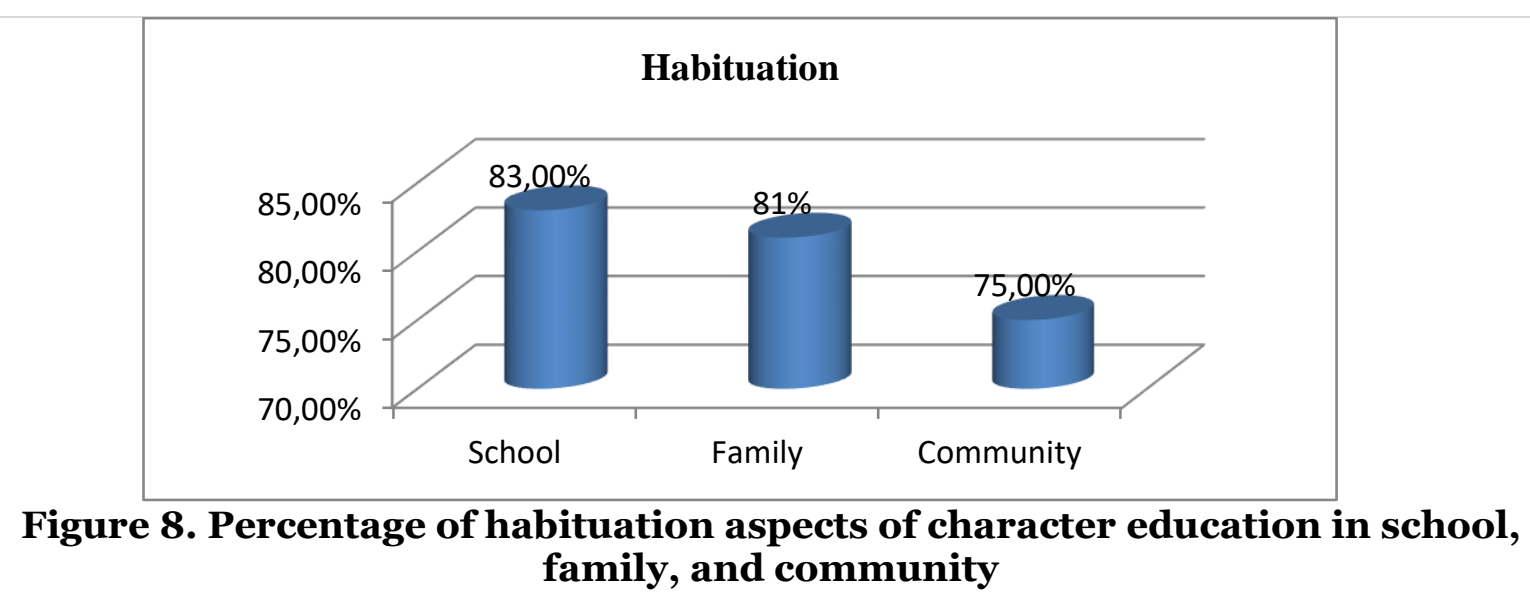

People of character were people who knew good things, loved good, and did well. Good character can be formed with education. Character education included knowledge, feelings, and actions (Rosad, 2019). Implementation of character education can be through learning, exemplary, reinforcement, and habituation. In one study, characterless people had a high potential to engage in characterless acts such as cyber-bullying (Gao et al., 2020).

In Indonesia, character learning was taught explicitly in the curriculum or implied lessons integrated into character values. Civics and Islamic Religious Education subjects were one part of character learning. This subject was taught to students from the lowest and highest level schools (Tim Observer, 2021). Suppose the value of character education was implemented through Civics. In that case, it could be said that the character values for Civics include the principal of the main character and the value of the main character. The principal character values of Civics were to create students who were: religious, honest, intelligent, authoritarian, democratic, and caring. While the central character values of Civics were to create students who were: nationalist, obedient to social rules, respect diversity, aware of the rights and obligations of self and others, responsible, think logically, critically, creatively, innovatively, and independently. These central character values can be developed more broadly to strengthen the function of Civics as character education (Dianti, 2014; Juliardi, 2015). Whereas in Islamic religious education, the characters that can be instilled were religion, honest, tolerance, discipline, hard work, creativity, independence, democratic, curiosity, national spirit, love for the homeland, respect for achievement, friendly, communicative, peaceloving, fond of reading, environmental care, social care, responsibility through the material of the Qur'an, aqidah, fiqh, morality, and history (Mamlu'ah, 2016).

The observations showed that $87.5 \%$ of character learning was obtained through Civics and Islamic Religious Education subjects. Learning was given for two hours of lessons equivalent to 90 minutes per week. Moreover, $75 \%$ of character learning was obtained in the community (Tim Observer, 2021). Character education through character learning must be carried out in a planned manner. The results of research in Indonesia and Malaysia showed that character education in schools was carried out programmatically, starting from the formulation of plans to evaluation (Karuniawati \& Nadeak, 2021). In a study, learning preparation starting from prayer and checking the neatness of students' uniforms, the learning process by teaching teamwork, and closing the teaching and learning process by praying and greetings were positively correlated in character building (Marini et al., 2019). Character learning can also be carried out through an integration process in routine activities at school, exemplary, conditioning in other subjects, and school culture as a student learning environment (Lubis \& Nasution, 2017; Sardiman, 2012).

The same thing was also found in a study that showed a positive relationship between extracurricular activities and student character (Han et al., 2017). The student-teacher relationship and the motivation given to students in the school environment increased positive development in students, such as students' beliefs about their future and so on (Alm et al., 2019). However, character values other than those contained in school regulations such as etiquette for older and younger 
people, caring, honesty are still cognitive. The study's findings align with previous research that most teachers had not optimally implemented character education for their students (Citra, 2012) and still only took place in the cognitive realm (Barus, 2015). In the case of online learning, most students were not honest in doing assignments. This case was in line with the results of Hadayani's research which showed that $61.4 \%$ of students practiced religion, $14.4 \%$ did not practice it, and $20 \%$ had not instilled the values of honesty and politeness while studying at home (Hadayani et al., 2021).

Exemplary was important in character education. Education through exemplary was better than education through discipline, which caused physical and psychological punishment. Research in Taiwan showed that physical and psychological punishment would only cause persecution for students (Chen et al., 2020). Persecution and violence from teachers, parents, or adults were factors that caused behavioral deviations socially (Nkuba et al., 2019). A study showed that the level of education through applying discipline in schools fostered punishment support disproportionately targeting minorities (Welch, 2018). A study showed that adolescent character deviation would cause depressive symptoms in adulthood ( $\mathrm{J}$. Kim et al., 2020). Attitudes of depression, anxiety, stress significantly predicted suicidal ideation (Jie Zhang et al., 2017). Exemplary was also part of strengthening character education (Dwintari, 2017). The study results showed $75 \%$ of the level of exemplary in the community and $78.75 \%$ in the school and family environment (Tim Observer, 2021). This obstacle showed that the exemplary had not been optimally provided in schools.

In contrast, the exemplary in the family and community was still minimal because of the busyness and lack of care from each party (Tim Observer, 2021). Students' character was strongly influenced by the school environment, family, and community where the child grew up (Sudrajat, 2011). The results of previous studies showed that the family environment dominated students' character by $10.6 \%$, the school environment by $8.40 \%$, and the community environment by $8 \%$ (Muhardi, 2016). Similarly, it was also found that school climate significantly influenced problem behavior (Ly et al., 2021; Reaves et al., 2018). This contrasts with research found in China which stated that school climate did not affect adolescent acquaintances (Jingyi Zhang et al., 2020).

The reinforcement of character education can be in school regulations such as dress codes, school on time, religious extracurricular activities, Youth Red Cross and Scouts, routine supervision by parents and family, or activities and policies in the community. In a study, the reinforcement of character in students in Magelang Raya occurred because it was supported by good local wisdom values (Sukron Mazid, Danang Prasetyo, 2020). The peer group environment was an essential part of strengthening character education. Social friends were friends where children often gather (Suryana, 2016). Partners had a significant influence on character (Susanto, 2016), especially for college students. A study showed that the delinquent behavior of girls was more susceptible to influence than boys (McMillan, C., Felmlee, D., \& Osgood, 2018), and boys had a much higher involvement of aggressive and non-aggressive delinquents than girls (Liu \& Miller, 2020). Students who had a friendly environment with bad personalities were the cause of character deviations. Bullying was one example of character deviation. In one study, both bullies and victims were equally vulnerable to threatening and attacking behavior (Hong et al., 2021). The history of student delinquency was needed as a protective attachment as reinforcement of character that functioned as a monitor of student character from time to time (Lee et al., 2018).

Students who were still in the stage of emotional development and were looking for identity, were indeed easily influenced by peers because of their loyalty to their friends. A study showed that adolescents who were in contact with delinquent peers were more likely to become victims and perpetrators of bullying in the form of physical, verbal, and social bullying (Cho \& Lee, 2018). The findings showed that the reinforcement of character values was $88.75 \%$ in the school, $75.25 \%$ in the family, and $73.50 \%$ in the community environment. While at the junior high school level, in the form of regulations, motivation, supervision, communication, and feedback on student behavior was carried out by the homeroom teacher, a small number of teachers, families, and the community (Tim 
Observer, 2021). Periodic family supervision of student behavior also had an essential role in strengthening character education in schools. In a study that was collaborated between schools and parents of students was able to reduce the level of juvenile delinquency (Sabatine et al., 2017), parents' mistakes in educating their children were one of the causes of student character deviations (Suyadi et al., 2021; Yuniati A, 2017). The perception that teacher support and care for students was a reinforcement in character education because it can be part of prevention programs in schools (Forster et al., 2017).

To obtain maximum character education, it was necessary to familiarize students in the school, family, or community environment. Habituation was an essential factor in instilling noble character in students. Parenting and learning patterns were part of forming habits. Research in Malaysia, authoritative parenting had a significant relationship to students' morals towards God and themselves (Ghani et al., 2014). If the environment were good, students would get used to behaving well. In a study, it was shown that the school environment affected students' character (Ardiyansyah et al., 2019). Habituation can also be done using teaching materials that contained good values (Nugrahani, 2017) and became a school strategy in shaping students' character (Faradiba \& Budiningsih, 2021; Suriansyah \& Aslamiah, 2015). Policies in the school environment influenced character. In one study, the efforts of educators and policymakers seeking to prevent and reduce delinquency and teacher training on signs of lack of character in the form of aggression or violence were able to shape students' character and reduce delinquency in schools (Le \& Stockdale, 2011).

Technological advances in the global era were one of the causes of the decline in character values in students outside the realm of research. In today's era, students were not far from cell phones. Students can access many things through their mobile phones. A study showed that character deviations in cyberspace were getting higher (Bae, 2017). The results showed an effect of using gadgets on students' character, namely the higher the use of gadgets, the children tended to be apathetic, irrational, lazy, closed, lacked empathy for others, and individualistic (Rahmandani et al., 2018).

The findings of this study indicated that the inculcation of character values in the habituation factor in the school environment was $83.00 \%$, the family was $81 \%$, and community was $75 \%$. In schools, habituation was carried out through school rules and policies. In this study, habituation was dominated by the school environment, then in the family and community environment with a reduced percentage, but still relatively high. Habituation of good behavior at school was not an obstacle to the decline of character values in students (Tim Observer, 2021).

\section{CONCLUSION}

This study concluded that the lack of exemplary, reinforcement, and habituation was a factor in the decreased understanding and reflection of student behavior character values. Furthermore, learning about character values was integrated through Civics and Islamic Religious Education subjects. While the exemplary provided by the school, family, and community, reinforcement in the form of regulations, policies, and cooperation between schools, families, and communities regularly and habituation of living with character in daily life was still not optimal. It needed to be optimized again so that the character values in students were closely and maximally attached to students both from speech and action.

\section{REFERENCES}

Achmad, Y. (2020). Pendidikan Karakter Indigenous Dalam Perspektif Al-Qur'an. Alim | Journal of Islamic Education, 2(1), 45-74. https://doi.org/10.51275/alim.v2i1.159

Alm, S., Låftman, S. B., Sandahl, J., \& Modin, B. (2019). School effectiveness and students' future orientation: A multilevel analysis of upper secondary schools in Stockholm, Sweden. Journal of Adolescence, 70, 62-73. https://doi.org/10.1016/j.adolescence.2018.11.007

Anwar, S. (2016). Peran Pendidikan Agama Islam dalam Membentuk Karakter Bangsa. Al Tadzkiyyah:Jurnal Pendidikan Islam, 7(1). 
Ardiyansyah, H., Hermuttaqien, B. P. F., \& Wadu, L. B. (2019). Pengaruh Lingkungan Sekolah Terhadap Moral Siswa Sekolah Menengah Pertama Se Kecamatan Bantur. Jurnal Moral Kemasyarakatan, 4(1), 1-7. https://doi.org/10.21067/jmk.v4i1.2977

Asa, A. I. (2019). Pendidikan Karakter Menurut Ki Hadjar Dewantara Dan Driyarkara. Jurnal Pendidikan Karakter, 9(2). https://doi.org/10.21831/jpk.v9i2.25361

Bae, S. M. (2017). The influence of strain factors, social control factors, self-control and computer use on adolescent cyber delinquency: Korean National Panel Study. Children and Youth Services Review, 78, 74-80. https://doi.org/10.1016/j.childyouth.2017.05.008

Barus, G. (2015). Menakar Hasil Pendidikan Karakter Terintegrasi Di Smp. Jurnal Cakrawala Pendidikan, 2(2), 222-233. https://doi.org/10.21831/cp.v2i2.4827

Borzekowski, D. L. G. (2018). A quasi-experiment examining the impact of educational cartoons on Tanzanian children. Journal of Applied Developmental Psychology, 54, 53-59. https://doi.org/10.1016/j.appdev.2017.11.007

Chen, J. K., Wu, C., \& Wei, H. S. (2020). Personal, family, school, and community factors associated with student victimization by teachers in Taiwanese junior high schools: A multi-informant and multilevel analysis. Child Abuse and Neglect, 99, 104246. https://doi.org/10.1016/j.chiabu.2019.104246

Cho, S., \& Lee, J. M. (2018). Explaining physical, verbal, and social bullying among bullies, victims of bullying, and bully-victims: Assessing the integrated approach between social control and lifestyles-routine activities theories. Children and Youth Services Review, 91, 372-382. https://doi.org/10.1016/j.childyouth.2018.06.018

Citra, Y. (2012). Pelaksanaan Pendidikan Karakter Dalam Pembelajaran. E-JUPEKhu (JURNAL $\begin{array}{llll}\text { ILMIAH PENDIDIKAN KHUSUS), 237-249. } & \text { 1(1), }\end{array}$ http://ejournal.unp.ac.id/index.php/jupekhu/article/view/795

Dianti, P. (2014). Integrasi Pendidikan Karakter dalam pembelajaran Pendidikan Kewarganegaraan untuk mengembangkan karakter siswa. Jurnal Pendidikan Ilmu Sosial, 23(1).

Dwintari, J. W. (2017). Kompetensi Kepribadian Guru dalam Pembelajaran Pendidikan Kewarganegaraan Berbasis Penguatan Pendidikan Karakter. Jurnal Pendidikan Kewarganegaraan, 7(2). https://ppjp.ulm.ac.id/journal/index.php/pkn/article/view/4271

Faradiba, D. G., \& Budiningsih, A. (2021). Pengembangan media komik berbasis pendidikan karakter peduli sosial pada pembelajaran tematik-integratif. Jurnal Inovasi Teknologi Pendidikan, 7(2). https://doi.org/10.21831/jitp.v7i2.24758

Forster, M., Gloppen, K. M., Gower, A. L., Oliphant, J. A., Sieving, R. E., \& McMorris, B. J. (2017). Associations Between Multiple Dimensions of School Engagement, Peer Relationships, and Risky Health Behaviors Among Vulnerable Middle School Students. Journal of Adolescent Health, 6o(2), S31-S32. https://doi.org/10.1016/j.jadohealth.2016.10.079

Gao, L., Liu, J., Wang, W., Yang, J., Wang, P., \& Wang, X. (2020). Moral disengagement and adolescents' cyberbullying perpetration: Student-student relationship and gender as moderators. Children and Youth Services Review, 116, 105119. https://doi.org/10.1016/j.childyouth.2020.105119

Ghani, F. B. A., Kamal, S. L. bt A., \& Aziz, A. bt A. (2014). The Implication of Parenting Styles on the Akhlak of Muslim Teenagers in the South of Malaysia. Procedia - Social and Behavioral Sciences, 114, 761-765. https://doi.org/10.1016/j.sbspro.2013.12.781

Gunawan, Y., \& Hafiz, M. B. A. (2020). Sekolah Ramah HAM Sebagai Upaya Penanggulangan Tindakan Kekerasan Di Kalangan Siswa. Jurnal Pengabdian Kepada Masyarakat Membangun Negeri, 4(2).

Hadayani, T., Utami, N., \& Abdullah, K. (2021). Implementation of Religious Character Education in Online Learning for Elementary School. Proceedings of the 1st Annual International Conference on Natural and Social Science Education (ICNSSE 202O), 547(Icnsse 2020), 66- 
72. https://doi.org/10.2991/assehr.k.210430.010

Han, S., Lee, J., \& Park, K. G. (2017). The impact of extracurricular activities participation on youth delinquent behaviors: An instrumental variables approach. Journal of Adolescence, 58, 84-95. https://doi.org/10.1016/j.adolescence.2017.05.006

Hasan, S. H. (2011). Pengembangan Pendidikan Budaya dan Karakter Bangsa. Badan Penelitian dan Pengembangan Pusat Kurikulum.

Hong, J. S., Chen, J. K., Wang, S. C., Lee, J. M., Algood, C. L., \& Voisin, D. R. (2021). What types of delinquent activities are bullies, victims, and bully/victims in urban neighborhoods most likely involved in? Journal of Pediatric Nursing, 59, 55-62. https://doi.org/10.1016/j.pedn.2020.12.019

ICRW. (2015). Debat Final: 84\% Anak Indonesia Alami Kekerasan di Sekolah. Datoboks. https://databoks.katadata.co.id/datapublish/2017/02/10/84-anak-indonesia-alamikekerasan-di-sekolah

Julaeha, S. (2019). Problematika Kurikulum dan Pembelajaran Pendidikan Karakter. Jurnal Penelitian Pendidikan Islam, 7(2), 157. https://doi.org/10.36667/jppi.v7i2.367

Juliardi, B. (2015). Implementasi Pendidikan Karakter Melalui Pendidikan Kewarganegaraan. Jurnal Bhinneka Tunggal Ika, 2(2), 3.

Karuniawati, \& Nadeak, B. (2021). the Effect of Character Education and the Role of Teachers on the Competency of Students in Accounting and Finance Program Smkn 1 Toraja Utara. International Journal of Research -GRANTHAALAYAH, 9(2), 241-247. https://doi.org/10.29121/granthaalayah.v9.i2.2021.3525

Kim, J., Kim, R., Oh, H., Lippert, A. M., \& Subramanian, S. V. (2020). Estimating the influence of adolescent delinquent behavior on adult health using sibling fixed effects. Social Science and Medicine, 265, 113397. https://doi.org/10.1016/j.socscimed.2020.113397

Kim, S., Choe, I., \& Kaufman, J. C. (2019). The development and evaluation of the effect of creative problem-solving program on young children's creativity and character. Thinking Skills and Creativity, 33. https://doi.org/10.1016/j.tsc.2019.100590

Lavy, S. (2020). A Review of Character Strengths Interventions in Twenty-First-Century Schools: their Importance and How they can be Fostered. Applied Research in Quality of Life, 15(2), 573-596. https://doi.org/10.1007/s11482-018-9700-6

Le, T. N., \& Stockdale, G. (2011). The influence of school demographic factors and perceived student discrimination on delinquency trajectory in adolescence. Journal of Adolescent Health, 49(4), 407-413. https://doi.org/10.1016/j.jadohealth.2011.02.003

Lee, S. Y., Rhee, S., \& Villagrana, M. (2018). Change in delinquency over time between adolescents with and without maltreatment experiences: Attachment and the school's role. Children and Youth Services Review, 86, 110-119. https://doi.org/10.1016/j.childyouth.2018.01.015

Li, Q., \& Cheng, T. C. (2017). New evidence in physical violent behaviors among school-aged children: A multiple disadvantages model. Children and Youth Services Review, 81, 301-308. https://doi.org/10.1016/j.childyouth.2017.08.021

Liu, L., \& Miller, S. L. (2020). Protective factors against juvenile delinquency: Exploring gender with a nationally representative sample of youth. Social Science Research, 86, 102376. https://doi.org/10.1016/j.ssresearch.2019.102376

Lubis, R. R., \& Nasution, M. H. (2017). Implementasi Pendidikan Karakter di Madrasah Ibtidaiyah. JIP (Jurnal Ilmiah PGMI), 3(1), 15-32.

Ly, D. B., Dudovitz, R. N., Rünger, D., Jackson, N. J., \& Wong, M. D. (2021). Chaos in Schools and Its Relationship to Adolescent Risk Behaviors. Academic Pediatrics, 21(2), 329-335. https://doi.org/10.1016/j.acap.2020.08.015

Mamlu'ah, A. (2016). Implementasi Pendidikan karakter Dalam Pembelajaran PAI. Al Ulya: Jurnal Pendidikan Islam, 1(1), 123-137.

Marini, A., Maksum, A., Edwita, E., Satibi, O., \& Kaban, S. (2019). School management on the basis 
of character building in teaching learning process. Journal of Physics: Conference Series, 1402(2), 022067. https://doi.org/10.1088/1742-6596/1402/2/022067

Marzuki. (2018). Penanaman Nilai-Nilai Karakter Religius Dan Karakter Kebangsaan di Madrasah Tsanawiyah Al Falah Jatinangor Sumedang. Jurnal Pendidikan Karakter, 8(1). https://doi.org/10.21831/jpk.v8i1.21677

McMillan, C., Felmlee, D., \& Osgood, D. . (2018). How network processes shape adolescent smoking, dringking and delinquency. Social Networks, 55(86-96).

Muhardi. (2016). Faktor Penyebab Perilaku Menyimpang Siswa SMP. Jurnal Untan, 5(10).

Munawwaroh, A. (2019). Keteladanan Sebagai Metode Pendidikan Karakter. Jurnal Penelitian Pendidikan Islam, 7(2), 141. https://doi.org/10.36667/jppi.v7i2.363

Nkuba, M., Hermenau, K., \& Hecker, T. (2019). The association of maltreatment and socially deviant behavior--Findings from a national study with adolescent students and their parents. Mental Health and Prevention, 13, 159-168. https://doi.org/10.1016/j.mhp.2019.01.003

Nugrahani, F. (2017). The Development of Film-Based Literary Materials which Support Character Education. Jurnal Cakrawala Pendidikan, 36(3). https://doi.org/10.21831/cp.v36i3.14219

Padjrin, P. (2016). Pola Asuh Anak dalam Perspektif Pendidikan Islam. INTELEKTUALITA, 5(1), 1. https://doi.org/10.19109/intelektualita.v5i1.720

Rachmadyanti, P. (2017). Penguatan Pendidikan Karakter Bagi Siswa Sekolah Dasar Melalui Kearifan Lokal. JPSD, 3(2), 201-214.

Rahmandani, F., Tinus, A., \& Ibrahim, M. M. (2018). Analisis Dampak Penggunaan Gadget (Smartphone) Terhadap Kepribadian Dan Karakter (Kekar) Peserta Didik Di Sma Negeri 9 Malang. Jurnal Civic Hukum, 3(1), 18. https://doi.org/10.22219/jch.v3i1.7726

Reaves, S., McMahon, S. D., Duffy, S. N., \& Ruiz, L. (2018). The test of time: A meta-analytic review of the relation between school climate and problem behavior. Aggression and Violent Behavior, 39, 100-108. https://doi.org/10.1016/j.avb.2018.01.006

Rosad, A. M. (2019). Implementasi Pendidikan Karakter Melalui Managemen Sekolah. Tarbawi: $\begin{array}{lllll}\text { Jurnal Keilmuan } & \text { Manajemen } & \text { Pendidikan, } & \text { 5(02), } & \end{array}$ https://doi.org/10.32678/tarbawi.v5io2.2074

Sabatine, E., Lippold, M., \& Kainz, K. (2017). The unique and interactive effects of parent and school bonds on adolescent delinquency. Journal of Applied Developmental Psychology, 53, 54-63. https://doi.org/10.1016/j.appdev.2017.09.005

Saptatiningsih, R. I., Wardani, S., \& Widya, S. M. (2021). Applying information and communication technology on learning model innovation of character education. Journal of Physics: Conference Series, 1823(1). https://doi.org/10.1088/1742-6596/1823/1/012057

Sardiman, M. (2012). Interaksi dan Motivasi Belajar Mengajar. Rajawali Pers.

Sudrajat, A. (2011). Mengapa Pendidikan Karakter. Jurnal Pendidikan Karakter, I(1), 47-58. https://doi.org/10.21831/jpk.v1i1.1316

Sukron Mazid, Danang Prasetyo, dan F. (2020). Nilai-Nilai Kearifan Lokal Sebagai Bentuk Karakter Masyarakat. Jurnal Pendidikan Karakter, 10(2).

Suriansyah, A., \& Aslamiah. (2015). Strategi Kepemimpinan Kepala Sekolah, Guru, Orang Tua, Dan Masyarakat Dalam Membentuk Karakter Siswa. Jurnal Cakrawala Pendidikan, 2(2), 234-247. https://doi.org/10.21831/cp.v2i2.4828

Suryana, D. (2016). Pendidikan Anak Usia Dini, Stimulasi dan Aspek Perkembangan Anak. Kencana.

Susanto, I. (2016). Pengaruh Kelompok Teman Sebaya Terhadap Perilaku Menyimpang Peserta Didik di Sekolah (Studi Deskriptif di kelas X SMA Pasundan 3 Bandung). In Doctoral dissertation, FKIP UNPAS.

Sutarna, N., Cahyo, E. D., Agustan, B., \& Mulyana, N. (2021). Character Education of Muhammadiyah. Proceedings of the 1st Paris Van Java International Seminar on Health, 
Economics, Social Science and Humanities (PVJ-ISHESSH 2020), 535, 202-205. https://doi.org/10.2991/assehr.k.210304.042

Suyadi, S., Susilowati, S., \& Supriyatno, T. (2021). Islamic Character Education for Student of Public Higher Education in Indonesia. Proceedings of the International Conference on Engineering, Technology and Social Science (ICONETOS 2020), 529. https://doi.org/10.2991/assehr.k.210421.086

Suyanto, S. (2012). Pendidikan Karakter Untuk anak usia dini. Jurnal Pendidikan Anak, 1(1).

Tang, X., Li, Y., Duan, W., Mu, W., \& Cheng, X. (2019). Character strengths lead to satisfactory educational outcomes through strength use: A longitudinal analysis. Frontiers in Psychology, 1O(AUG), 1829. https://doi.org/10.3389/fpsyg.2019.01829

Tim Observer. (2021). Hasil Angket Pada Siswa Sekota Palembang.

Virgustina, N. (2019). Implementasi Pendidikan Karakter Melalui Budaya Sekolah Pada Siswa Sekolah Menengah Kejuruan. KELUARGA: Jurnal Ilmiah Pendidikan Kesejahteraan Keluarga, 5(2), 365. https://doi.org/10.30738/keluarga.v5i2.3842

Welch, K. (2018). The effect of minority threat on risk management and the "new disciplinology" in $\begin{array}{llll}\text { schools. Journal of Criminal } & \text { Justice, } & 59, & 12-17 .\end{array}$ https://doi.org/10.1016/j.jcrimjus.2017.05.006

Yuniati A. (2017). Perilaku Menyimpang dan Tindak Kekerasan Siswa SMP di Kota Pekalongan. Jurnal Bimbingan Konseling, 6(1), 77-83.

Zhang, Jie, Liu, Y., \& Sun, L. (2017). Psychological strain and suicidal ideation: A comparison between Chinese and US college students. Psychiatry Research, 255, 256-262. https://doi.org/10.1016/j.psychres.2017.05.046

Zhang, Jingyi, Li, D., Ahemaitijiang, N., Peng, W., Zhai, B., \& Wang, Y. (2020). Perceived school climate and delinquency among Chinese adolescents: A moderated mediation analysis of moral disengagement and effortful control. Children and Youth Services Review, 116(105253). https://doi.org/10.1016/j.childyouth.2020.105253

Zuhdi, D. (2011). Pendidikan Karakter dalam Perspektif Teori dan Praktik. Yogyakarta: UNY Press. 